\title{
醬油の火入れ製成工程での濾過技術 と色度調整
}

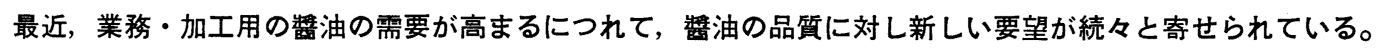
濃口は濃口なりに色淡く, 淡口は白樽油のような淡色なものが要求され, 併せて生菌数, 濁度等についても厳 しいチェックをうけるようになってきた。

このようなユーザーの注文に適する品質のものを間違いなく製造する方法について，新しい研究結果を基に解 説していただいた。

奥 沢 洋 平

は じめに

火入れ製成工程は加熱による殺菌, 酵素の失活, 色調 の増進, 火香の付与, オリ除去等の役割を持ち, 醬油醸 造の重要な工程の一つである。近年, 加工用を中心に淡 口醬油, 白醬油の需要が増加しているが, 濃口醬油にお いてもより淡色なものが好まれる傾向にある。特に, 加 工用の場合は色調に対する要求が一段と䈗しく中小メー カーにとって着色の調整はもっとも重要な技術のひとつ と思われる。さらに, 加工用においては無菌化, 透明度 の向上等の要求もみられる。これらの要求に対応するた め中小メーカーに拉いても膜技術等の新技術の導入も必 要と思われる。ただし, 新技術の検討に打いて, これま では加熱, オリ凝集, 沈降, 濾過という従来の工程の代 替または補完という使用方法が多かったと思われる。こ れに対して最近は工程を変更する, 特にオリの沈降期間 を短縮あるいは削除するような处理方法が提案されてお り注目される。また, 従来からある濾過機を用いた火入 醬油（オリ引前の混濁醬油）の全量濾過も可能であり, この場合もオリの沈降期間を短縮できる。このように現 在, 火入れ製成工程の機能として何に重点を置くかによ って多様な選択が可能である。

本稿では火入工程において基本となる着色の調整につ いて述べ, 生揚醬油の限外濾過, 火入醬油の精密濾過, 火入醬油の全量濾過, シリカゾルの利用, 高温短時間殺 菌について, 工程の改変と着色調整, 無菌化等の品質制 御の二面から濃口醬油を対象に検討したので,これらに ついて述べてみたい。

\section{1. 火入れ工程における着色の調整}

当県では醬油製造におけるカラメルの使用例は標準品 等一部のみで非常に少ない。これは淡色化の傾向に加 兄, 高窒素製品が増加し着色しやすくなったことと自然 食指向からカラメルといえども添加しない傾向がみられ るからである。従って, 従来であればカラメルの添加に より色の調整ができたが, 現在は加熱温度の制御により 着色を調整する必要が生じてきた。火入工程において醬 油の色の 40〜50\% が生成されるため色度調整に括ける 本工程の影響は大きい。清澄タンクでの着色の進行を色 度計でモニターすれば最も確実に調整できるが中小メー カーではコスト的に困難である。そこで着色の予測から 調整を行うこととした。火入工程での着色予測について は茂田井らの研究があるためこれを参考とし, 醬油工 場に和汀る火入程の調查結果から, 県内の実状に適合 するよう予測式を改変しパソコンを用いて予測計算を行 ったのでその概略を述べる。

着色予測には清澄タンクでの醬油の品温経過の予測と 品温経過に基づく着色反応の予測とが必要である。品温 経過は熱移動の速度式 (1) から求められる。

$$
\begin{gathered}
\frac{d t}{d \theta}=\frac{U A}{W}\left(t-t_{r}\right) \\
\ln \left(\frac{t_{0}-t_{r}}{t-t_{r}}\right)=\frac{U A}{W} \cdot \theta
\end{gathered}
$$

$U:$ 総括伝熱係数, $A:$ 伝熱面積, $W$ : 熱容量,

$\theta:$ 時間, $t_{0}$ : 初発温度, $t_{r}$ : 室温, $t:$ 醬油温度

まず各々の清澄タンクの総括伝熱係数 $(U)$ を求める ため実際の温度経過を測定する。各経過時間ごとに(2)

Control of Coloration and filtration of Soy Sauce during Pasteurization

Youhei OKUZAWA (Saitama Research Institute of Food Technology) 


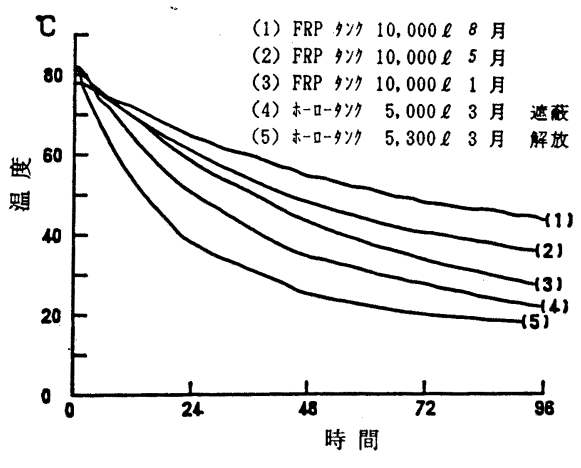

第 1 図 火入れ後放冷中の醬油品温経過

式の左辺を計算し時間との関係をグラフ化する。その直 線の傾きが $U A / W$ であるのでU值が求められる。な お, 水分の蒸発がある場合はビニールシート等で開口部 を遮断して蒸発を押光温度経過を測定する必要がある。 温度経過に対する水分蒸発の影響は大きいので水分の蒸 発がある場合はこの予測が不可欠であり, 温水表面から の蒸発量の計算 を参考に行った。ただし，醬油表面か らの蒸発量は水に比べて少ないので $50 \sim 80^{\circ} \mathrm{C}$ での実験 から醬油表面の相対温度を $57 \%$ と仮定して計算した。

品温経過に影響する要因としては醬油量, タンク表面 積, タンク材質, 初発品温, 室温, 開口面積(蒸発面積) 等がある。タンク容量が大きくなると醬油量に対する表 面積の比が小さくなるので领めにくくなり, 当然のこと ながら冬より夏は冷めにくい。実際の調查結果の一例を 第 1 図に示す。何れもプレートヒーターで加熱し直ちに 清澄タンクに移送しており, この移送時間中の清澄タン ク内の醬油品温は比較的安定している。これはタンク及 び醬油表面からの放熱が流入する醬油の熱量で補われる ためと考兄られる。従って, プレートヒーター出口と清 澄タンク内の品温には数 ${ }^{\circ} \mathrm{C}$ 差がある。プレートヒータ 一からタンクをでの移送パイプ中に存在する時間は短い ので着色には核とんど影響しないと思われるため, 実際 的な火入れ温度は移送時間中の清澄タンク内の品温であ る。また,この温度差には（1）式の諸要因と移送速度 が影響する。移送速度が小さく，開放タンクを使用して いる工場では温度差が $8^{\circ} \mathrm{C}$ 以上になる例もみられた。 $80^{\circ} \mathrm{C}$ 付近での $1^{\circ} \mathrm{C}$ の差は無視できない影響を与えるの でこの温度差にも注意が必要である。

着色反応速度と温度, 諸成分濃度との関係は次式で示 される1)。

$$
\ln k=\alpha+\beta t
$$

$k$ : 着色反応速度係数 $\left(\Delta E_{450} / \mathrm{hr}\right), t:$ 品温

$\alpha, \beta$ は定数で， $\beta$ 值は成分值に関係なくほぽ一定で あるが， $\alpha$ 值は成分值により変化する。加熱褐变はアミ
第 1 表 醬油火入れ清澄時の色度 (No) 減少值の 予測例 (冷却無)

\begin{tabular}{l|c|c|c|c}
\hline \multirow{2}{*}{ 火入温度 } & \multicolumn{3}{|c}{ 無塩可溶性固形分 } \\
\cline { 2 - 5 } & \multicolumn{2}{|c|}{$19.5 \%$} & \multicolumn{2}{|c}{$21 \%$} \\
\cline { 2 - 5 } & 気温 $10^{\circ} \mathrm{C}$ & 気温 $30^{\circ} \mathrm{C}$ & 気温 $10^{\circ} \mathrm{C}$ & 気温 $30^{\circ} \mathrm{C}$ \\
\hline $80^{\circ} \mathrm{C}$ & 6.1 & 9.3 & 8.4 & 12.8 \\
$82^{\circ} \mathrm{C}$ & 7.5 & 11.1 & 10.2 & 15.3 \\
$84^{\circ} \mathrm{C}$ & 9.1 & 13.3 & 12.5 & 18.3 \\
\hline
\end{tabular}

$5,400 l$ ホーロー密閉タンク 火入れ移送時間 50 分

ノ酸、ペプチドと糖との反応であるのでこれらの成分と $\alpha$ 值との相関が高いが, 測定の簡単な無塩可溶性固形分 との相関も比較的高かったのでこれを用いることにし た。筆者が用いている数值は

$$
\begin{gathered}
\beta=0.05 \quad \alpha=0.092 E_{X}-5.72 \\
E_{X} \text { : 無塭可溶性固形分 }
\end{gathered}
$$

醬油温度が $65^{\circ} \mathrm{C}$ 以下では加熱褐变だけではなく酸化裼 変の影響も現われるといわれるが，県内の醬油工場での 実測值との整合性を良くするため今のところ（3）式を そのまま使用している。（4）式から分かるように醬油 の成分が濃厚なほど着色しやすく, 特選, 超特選醬油の 場合には火入れ温度, 冷却等の調節が特に必要である。

パソコンによる計算は最も簡単な積分方法である台形 近似法を用いた。すなわち, 単位時間当たりの品温低下 を(1) 式から求め, 前品温から差し引いて次品温とし 前品温との平均值を現品温とする。この品温での単位時 間当たりの着色量を（3），(4) 式を用いて計算し前着 色量に加算する。あとはこれの繰り返しである。なお， シャワー冷却時の温度低下は別にU 值を求め自然放冷時 のU值に代えて計算する。これにより目標色度とするた めの初発品温, 冷却開始時間等が決定できる。予測の一 例を第 1 表に示す。表中の数が 8 であれば生醬油の色が No. 20 から火入れ後 No. 12 に減少するといら意味であ る。予測の効果を上げるためにも火入温度, 冷却速度等 の作業の正確さが重要である。この意味からも，また， 作業効率を上げる点からも火入工程の自動化は有効であ ると思われる。なお，冷却方法としてプレート式熱交換 器を用いた場合オリの沈降に影響することがある。シャ ワー冷却方式ではタンクの材質によっては冷却効率が悪 いが, プログラム温度調節器, 電磁弁等と組み合せると 簡易に, より有効な温度制御ができると考えている。

最近の市販濃口醬油の品質の傾向として淡色化を指摘 できるが, 香気の点でも以前より火香が弱くなっている と思われる。さらに, 業務用, 特に加工用では生臭があ る程度残っても色の淡いものが要求されるような場合も ある。このような場合も当然酵素の失活のため $80^{\circ} \mathrm{C}$ 以 
第 2 表 限外濾過膜透過䣽油の火入れオリ生成

\begin{tabular}{l|c|c|c}
\hline \multicolumn{1}{c|}{ 膜 種 } & 分画分子量 & オリ容量 & 上澄液の濁度 \\
\hline NTU 3050 & 20,000 & $0.7 \%$ & $3.3 \mathrm{ppm}$ \\
FUS 3081 & 30,000 & $0.7 \%$ 未満 & $3.7 \mathrm{ppm}$ \\
NTU 3150 & 50,000 & $2.7 \%$ & - \\
GR 40 PP & 100,000 & $9.3 \%$ & - \\
SF 401 & $0.1 \mu^{*}$ & $10.7 \%$ & - \\
原 液 & - & $19.7 \%$ & $23.6 \mathrm{ppm}$ \\
\hline
\end{tabular}

* 精密濾過膜

上の加熱は必須であるので急冷が必要になるが，オリの 沈降を図るため冷却は $60^{\circ} \mathrm{C}$ 前後で止めなければならな い。従って, 着色の抑制をさらに進めるためには室温近 くまでの冷却を可能としなければならない。このような 条件を満たせる方法について無菌化等の機能も含めて以 下記述する。

\section{2. 生揚げ醬油の限外滤過}

火入れオリの主体は生揚醬油中の酵素類が加熱変性し 凝集したものであり, 県内の諸味液汁の試験結果に打い ても各酵素活性と火入れオリ量との相関が高かった。従 って,この酵素類を除去することにより火入れオリの生 成をほとんどなくすことができる。数種の限外濾過(UF) 膜, 精密濾過 (MF) 膜を透過させた醬油を火入れした 結果, UF 膜においては分画分子量によって火入れオリ を汇とんど生成せず上澄液の濁度も市販品より低いもの が得られた(第 2 表)。このことは火入温度経過をどのよ らに設定してもほとんど問題がないことを意味し, 着色 の調整は容易となる。この方法は最初に濾過を行い, 次 に加熱をするため通常の火入工程とは全く逆になり, オリ下げのための清澄タンクは必要がなくなる。さらに 核酸系調味料使用上問題となるフォスファターゼを除去 できれば香気の点を除いて加熱の必要はない。UF 膜透 過醬油でのイノシン酸の残存経過を調べた結果, 適切な UF 膜を選ぶことにより核酸系調味料は分解されず保持 されることが分かった(第 3 表)。表中の $\mathrm{f}$ 膜は乾燥によ り劣化した膜で, この場合フォスファターゼの阻止率が 低くイノシン酸が分解された。一般に膜濾過は回分式で 行われるので, 容量減少率 $(R F)$ が高くなり保持液が濃

第 3 表 限外濾過膜透過醬油中でのイノシン酸の分解

\begin{tabular}{|c|c|c|c|}
\hline \multirow{2}{*}{ 膜 } & \multirow{2}{*}{$\begin{array}{l}\text { フォススファター } \\
\text { ゼ活性 }\end{array}$} & \multicolumn{2}{|c|}{ イノシン酸残存量 $\mathrm{mg} \%$} \\
\hline & & 0日 & 30日 \\
\hline NTU 3050 & $0.005 \mathrm{U} / \mathrm{ml}$ & 52 & 50 \\
\hline FUS 3081 & $0.0015 \mathrm{U} / \mathrm{ml}$ & 48 & 53 \\
\hline$f$ & $0.06 \mathrm{U} / \mathrm{m} l$ & 22 & 0 \\
\hline 火入醬油 & - & 55 & 52 \\
\hline 生揚醬油 & $2.5 \mathrm{U} / \mathrm{ml}$ & 4 & 0 \\
\hline
\end{tabular}

第 4 表 醬油の限外滤過透過液の醭素活性 $(\mathrm{U} / \mathrm{m} l)$

\begin{tabular}{|c|c|c|c|c|}
\hline 容量減少率 & & $\begin{array}{l}\text { 全プロテ } \\
\text { アーゼ }\end{array}$ & $\begin{array}{l}\alpha-了 ミ \bar{c} \\
-セ ゙\end{array}$ & $\begin{array}{l}\text { フォスファ } \\
\text { ターゼ }\end{array}$ \\
\hline \multirow[t]{2}{*}{1.1} & 透過液 & 0.7 & 28 & 0.00032 \\
\hline & 阻止率 & $(99.2 \%)$ & $(99.8 \%)$ & $(99.98 \%)$ \\
\hline \multirow[t]{2}{*}{5} & 透過液 & 0.9 & 29 & 0.00098 \\
\hline & 阻止率 & $(99.6 \%)$ & $(99.9 \%)$ & $(99.98 \%)$ \\
\hline \multirow[t]{2}{*}{10} & 透過液 & 2.2 & 106 & 0.0016 \\
\hline & 阻止率 & $(99.6 \%)$ & $(99.8 \%)$ & $(99.98 \%)$ \\
\hline \multirow[t]{2}{*}{15} & 透過液 & 3.2 & 145 & 0.0024 \\
\hline & 阻止率 & $(99.7 \%)$ & $(99.8 \%)$ & $(99.98 \%)$ \\
\hline \multirow[t]{2}{*}{20} & 透過液 & 5.6 & 190 & 0.0146 \\
\hline & 阻止率 & $(99.6 \%)$ & $(99.8 \%)$ & $(99.95 \%)$ \\
\hline
\end{tabular}

縮されたときの阻止率が問題となる。 $R F$ と酵素の関係 を調べた結果, FUS $02 \mathrm{C} 1 \mathrm{X}$ 膜では $R F$ に関わらず酵 素の阻止率の変化が少なく, 高 $R F$ では透過液の酵素活 性が增加した (第 4 表)。従って, この膜の場合 RF 10 位までの透過液であれば残存酵素活性は実用上無視でき ると考えられた。また, 酵素の阻止率からみて微生物の 除去は $100 \%$ 之思われるので菌数検查はすべてについて は行っていないが, 検査した範囲では微生物は検出され なかった。限外濾過生揚げ醬油は原液に比べ, より淡白 な傾向となり物性上変化するが, 淡色, 高窒素で除酵 素, 除菌されているなど加工原料としてのメリットは多 いと思われる。この方法は火入工程ではないが着色をも つとも抑制した製成工程と考学られる。

UF 膜の適用に当たっては膜の選択が問題となる。ま ず, 分画分子量の表示であるが膜メーカーによって測定 条件が異なり, 同じ分画分子量表示であっても分画特性 が同じとは言えない。極端な場合, 分画分子量で 2 倍以 上の差があるので醬油を用いて確認する必要がある。ま た， $R F$ が大きくなり保持液の濃縮が進むと膜モジュー ルの入口と出口の差圧が大きくなり, 最適な操作条件を 維持できなくなる。中空系の実用モジュールであれば内 径はできるだけ太いモジュールが適すると思われる。ま た，管状モジュールの場合でもUベント等によって単管 が 10 数 $\mathrm{m}$ 連結されたタイプでは同様な注意が必要であ る。また, 膜材質によって透過液の香気の官能結果に差 がみられる。膜メーカーごとにアルコール洗浄等の対策 があるようであるが効果の確認はしていない。操作上で の問題は浮遊物による流路の閉塞と空気との接触による 酸化褐変である。前者は管状膜では問題ないが, 流路の 狭いタイプでは $100 \mu$ 程度での前濾過が必要である。後 者は窒素置換等によりある程度防止できると思われるが あまり実施例はみられない。

\section{3. 精密滤過膜による火入れ混濁徆油の滤過}

火入れ後のまだ温度の高い醬油を耐熱性のあるセラミ 
ック膜 ${ }^{3)}$, テフロン膜(4)を用いて濾過する方法が発表され ている。MF 膜では生揚醬油中の酵素類の除去率が低い が，加熱変性し凝集した火入れオリの大きさは $0.79 \mu$ 以上あるので $0.2 \mu$ 位の $\mathrm{MF}$ 膜での除去が可能となる。 膜濾過の場合, 供給液を $1 \mathrm{~m} /$ 秒程度の速度で循還させ るのでオリの粒径が変化しないとも限らないが, オリた んぱく質自体が濾過層となる自己阻止型ダイナミック限 外濾過膜を形成していると考光られている。膜濾過にお いては一般に温度が高いほぞ透過流束が高くなり濾過効 率が良くなるが, セラミック膜での醬油濾過の場合, $80^{\circ} \mathrm{C}$ では $20^{\circ} \mathrm{C}$ の 3 倍の透過流束が得られたという。この方 法を従来の方法と対比してみると，これまでの清澄タン クを膜装置の保持液タンクとして用い,オリの分離を自 然沈降から圧力濾過に変えた方法と捉えることができ る。火入れオリの凝集を図るところまでは通常の火入れ と変わることはなく, また, 濾過効率を上げるため濾過 中の品温低下は好ましくないので着色の抑制, 調整との 兼合いを考慮する必要がある。しかし, 透過液は冷却で きるので従来のオリ下げ時間は短縮され, 必要なのは濾 過に要する時間だけとなる。その分清澄タンクの削減が でき, また, 除菌, 透明度の向上が可能となる。最終段 に管状モジュールあるいはセラミック回転平膜5), 特に 後者を用いれば回収率はかなり高くなると思われる。た だし,オリの凝集が不完全な場合は二次オリの生成が懸 念されるので, 着色抑制のための極端な冷却は検討が必 要と思われる。また, 比較的高い温度の醬油を循環させ ることになるので生揚げ醬油の濾過の場合よりも酸化褐 変への対策の必要性が高いと思われる。

\section{4. 濾過圧搾機による火入酎油の全量濾過}

前項の MF 膜のような高温での濾過ではないが, MF 膜の例と同様にオリ引き前の火入醬油を濾過する方法で ある6)。一般に濾過機ではオリ引き後の上澄部を濾過す るのでオリの流入は避けなければならない。しかしこ のオリの流入による濾過層の目詰まりは, オリ成分の急 増に対する濾過助剈のボディフィード量の一時的な不足 が一因であると考兄られる。むしろオリが均一に分散し ていればボディフィード量を濁度に応じて增加させるこ とができるので, 濾過面積を増せば濾過が可能になると いうことが本方法の基本である。その他の理由としては 定圧ポンプなので時間をかけて濾過できることが考兄ら れる。

プリコート量ケイソウ土 $1 \mathrm{~kg} / \mathrm{m}^{2}$, ボディフィード量 $0.3 \%$ で濾過面積 $8.7 \mathrm{~m}^{2}$ の濾過圧搾機を用い, 圧力 $0.5 \sim 2 \mathrm{~kg} / \mathrm{cm}^{2}$ で火入れ翌日の火入醬油 $5,000 l$ の濾過 を行った結果, 上澄部のみの滤過時の約 2 倍の時間を要
第 5 表 醬油火入れ条件と滤過液の二次オリ生成

\begin{tabular}{c|c|c}
\hline \hline $55^{\circ} \mathrm{C}$ での保持時間 & $80^{\circ} \mathrm{C}$ での!保持 & 二次オリの有無 \\
\hline 0 分 (十ケイソウ土) & 10 分 & 有 \\
40 分 (十ケイソウ土) & 10 分 & 有 \\
80 分 (十ケイソウ土) & 10 分 & 無 \\
4 時間 & 10 分 & 無 \\
0 & 3 時間 & 無 \\
\hline
\end{tabular}

プリコート: $1 \mathrm{~kg} / \mathrm{m}^{2}$

ボディフィード : $0.3 \%$ (火入時添加量 $0.2 \%$ )

したが全量を濾過でき，二次オリの生成もみられなかっ た。

従って, 本方法によってもオリ下げ期間の短縮が可能 であり，火入れオりを諸味に戻したり，膜濾過するなど の処理は不要となる。

さらに着色の抑制の可能性を調べるため, $80^{\circ} \mathrm{C}$ 達温 後 10 分間保持した後, 室温まで急冷するといら条件に おける二次オリ生成について検討した（第 5 表)。あら かじめケインウ土 $0.2 \%$ を混合し, $55^{\circ} \mathrm{C} 80$ 分保持後 $80^{\circ} \mathrm{C} 10$ 分間加熱するといら方法により二次オリの生成 はみられなかった。この条件では加熱時間が短いので耐 熱性菌はほとんど減少せず, 香気には生臭が残ったが, 着色の 調整範囲がひろくなるとともに調整も容易にな る。また, 濾過液の濁度は濾過助剂の粒度によって異な り, 粒度の細かいものを用いれば濾過速度は落ちるが透 明度は向上する。濾過機を使用する場合, 使用後のケイ ソウ土の処分が問題となるがセルロース系の濾過助剂を 用いれば燒却も可能なので問題は軽減する。

生醬油を加熱すると一般に鮮やかな赤味を帯びた色調 になり $\Delta A$ 值が高くなるといわれる。しかし，県内の工 場での火入れ時における着色の進行を調べると, 加熱時 間が短い間の $\Delta A$ は生醬油の $\Delta A$ よりも低い。生醬油の $\Delta A$ が高いほどこの傾向が強い。従って, 加熱時間を短 縮する方法に沶いてはやや鮮やかさに欠ける傾向となる のでこの点については今後さらに検討する必要がある。

\section{5. オリ下げの効率化}

シリカゾルの凝集作用を醬油のオリ下げに応用した研 究7), 特許8 があり,このタイプの清澄剤が市販されてい

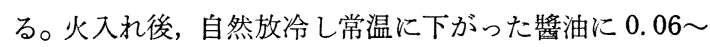
$0.1 \%$ 添加擋拌すると 24 時間以内にオリ下げが終了す るといら方法である。 $80^{\circ} \mathrm{C} 3$ 時間加熱後, 室温まで急冷 した後， 3 種類のシリカゾルを $0.1 \%$ 添加し，1 日静置 した後のオリ量と上澄液の濁度を調べた (第 6 表)。細 かい浮遊性のオリまで凝集するためか見掛けのオリ量は 通常の火入れ時に比べ少なくはなかったが, 表中 $\mathrm{A}, \mathrm{C}$ での清澄効果は明らかであった。一方, 火入れ前, 生嶈 
第 6 表 シリカゾルによる醬油火入れオリの沈降

\begin{tabular}{|c|c|c|c|c|}
\hline \multirow{2}{*}{$\begin{array}{l}\text { シリカゾ } \\
\text { ルの種類 }\end{array}$} & \multicolumn{2}{|c|}{ 䑧油 A } & \multicolumn{2}{|c|}{ 醬油 B } \\
\hline & オリ容量 & 上澄濁度 & オリ容量 & 上澄濁度 \\
\hline $\mathrm{A} 1$ & $14 \%$ & $19 \mathrm{ppm}$ & $24 \%$ & $25 \mathrm{ppm}$ \\
\hline A2 & $14 \%$ & $21 \mathrm{ppm}$ & $21 \%$ & $31 \mathrm{ppm}$ \\
\hline B & $13 \%$ & $42 \mathrm{ppm}$ & $9 \%$ & $83 \mathrm{ppm}$ \\
\hline C & $21 \%$ & $12 \mathrm{ppm}$ & $21 \%$ & $10 \mathrm{ppm}$ \\
\hline 無添加 & - & $82 \mathrm{ppm}$ & - & $107 \mathrm{ppm}$ \\
\hline
\end{tabular}

油に混合した後火入れを行うことができれば作業効率上 好ましいが, 冷却後添加したときに比べオリ下がりが悪 く, 上澄液の濁度の点でも劣った。火入れ時, 温度が高 い間に添加することは凝集反応が部分的に起こってしま らので澼けた方が良いといわれる。また，混合後あまり 時間を置かずに濾過を行い二次オリが生成した事例もあ る。このように効果的に使用する上でいくつか注意する 点はあるが, オリ下げ時間の短縮, 場合によっては濾過 の省略も可能なので有効な方法であると思われる。

\section{6. 高温短時間殺菌}

$100^{\circ} \mathrm{C}$ 以上での高温短時間殺菌は食品の殺菌方法とし て広く利用されている。醬油においても二次オリの生成 が注とんどなく，耐熱性の芽胞子細菌が少ない淡色な醬 油を得る方法として, 可及的急速に $90 \sim 130^{\circ} \mathrm{C}$ に昇温 し, この温度で 5 分以内保持し, ついで $60^{\circ} \mathrm{C}$ 以下に急 冷することを特徵とする火入れ法の特許が出されてい $ろ^{91}$ 。醬油の加熱温度と着色, 生菌数の減少との関係を みると、核济じょうな増色を与える加熱条件であって も, 高温になるほど生菌数の減少が大きいことが分かる (第 7 表)。なお, 表中 $110^{\circ} \mathrm{C}$ での加熱では他と加熱方法 が異なり達温までの時間が短いのでその分着色が少なか った。原液の生菌数が多いと無菌化するのにより長時間 の加熱が必要であり, 着色の抑制という点からも原液で の生菌数の低減,つまり製釈時の細菌数の低減が重要で ある。

第 7 表 醬油加熱条件と着色, 生菌数の関係

\begin{tabular}{c|c|c|c|c}
\hline \hline 加熱温度 & 加熱時間 & $\begin{array}{c}\text { 着 色 度 } \\
(450 \mathrm{~nm})\end{array}$ & 色度(No.) & 生菌数 $/ \mathrm{m} l$ \\
\hline $70^{\circ} \mathrm{C}$ & 9 時間 & 14.6 & 11 & $4.4 \times 10^{4}$ \\
$80^{\circ} \mathrm{C}$ & 3 時間 & 14.6 & 11 & $5.3 \times 10^{3}$ \\
$90^{\circ} \mathrm{C}$ & 1 時間 & 13.8 & 12 & $1.3 \times 10^{2}$ \\
$98^{\circ} \mathrm{C}$ & 21 分 & 14.1 & 12 & 6 \\
$110^{\circ} \mathrm{C}$ & 7 分 & 12.9 & 13 & 0 \\
\hline
\end{tabular}

高温短時間殺菌法は火入れの加熱方法として単独でも 用いられるであうろらが, 他の除菌効果の少ない方法を補 完するため他の方法と組及合せて用いるとより効果的で あると思われる。この組み合せによって, 着色の調整範 囲の拡大と清澄タンクの削減, 透明化, 無菌化が同時に 行える限外濾過法に近い機能をもつことができる。膜技 術に怙いても物性が变化十ろなど用途によっては欠点と なる特性もあり, 個々の方法の, あるいは組み合せた場 合の長所, 短所, 需要家の要求等を勘案しながら最も効 果的な方法を検討することが必要である。

\section{おわりに}

火入れ製成工程は醬油製造工程の最終工程であり, 当 然のことながら前工程の影響が大きい。例㓪ば，諸味熟 成工程での発酵が不足すると糖分が多く残り, 火入れで の着色反応が進行しやすくなり色度の調整に影響する。 また, 同じく諸味での乳酸発酵, アルコール発醥の多少 が火入れオリ量に影響する。生揚げ醬油の色が濃すぎた り, 冴えが悪ければ火入れでの調整では間に合わないこ とになる。火入れオリの沈降においても機構不明の現象 が多々あることから，火入れ製成工程での作業が順調に 進行するためにも原料処理以降の諸工程での適正な管理 が重要であると思われる。

（埼玉県食品工業試験場）

\section{文献}

1）茂田井 宏, 広岡仁史, 花岡嘉夫: 農化, 51, 107 (1977)

2）高村淑彦：ポケコンによる熱計算入門，(財)省エ ネルギーセンター

3）渡辺敦夫, 伊藤秀明, 中鴆光敏, 鍋谷浩志, 大谷 敏郎, 名和義彦：日食工誌, 37, 31 (1990)

4）品川雅一, 地蔵真一, 西田祐二, 藪下利男 : 食品 之開発, 25, No.7, 33 (1990)

5）高頭龍男，野垣 久，市瀬冬彦，北村正樹，兼国 伸彦: 第 34 回日本醬油研究所研究発表会講演要 旨, p. 14 (1991)

6）奥沢洋平, 平田裕子, 江口卯三夫 : 平成元年度埼 玉県食品工業試験場業務報告

7) 佐藤 信, 大場俊輝, 森 俊樹, 小樻正道, 渡部 淑㳙，田崎桂子：醸協，77，（8）553（1982）

8) 佐藤 信, 大場俊輝, 森 俊樹, 小櫃正道, 渡辺 淑䜌, 田崎桂子：特公, 昭 60-6187

9）茂田井 宏, 曾根原豪志, 石山 孝, 林 和也: 特公, 昭 62-25025 